PHARMACON- PROGRAM STUDI FARMASI, FMIPA, UNIVERSITAS SAM RATULANGI,

\title{
ANALISIS KORELASI ANTARA FLAVONOID TOTAL DENGAN AKTIVITAS ANTIBAKTERI EKSTRAK DAN FRAKSI DAUN \\ GEDI HIJAU (Abelmoschus manihot L.)
}

\author{
Josua A.T. Suoth ${ }^{1)}$, Sri Sudewi ${ }^{1)}$, Defny S. Wewengkang ${ }^{1)}$ \\ ${ }^{1)}$ Program Studi Farmasi FMIPA UNSRAT Manado, 95115
}

\begin{abstract}
One chemichal component that is often reported to have pharmacological activity against treatment or prevention of disease is flavonoids which can be found in gedi hijau leaves. Staphylococcus aureus is the main cause of infection in humans which can cause various severe infections. This study aims to determine the total flavonoids content, minimum inhibitory concentration (MIC). To determine the correlation between total flavonoids and antibacterial activity of extract and fractions (Abelmoschus manihot L.), The method of this study was done by obtaining the results of total flavonoid content, testing the antibacterial activity by dilution using a positive control of ciprofloxacin. The results showed the highest total flavonoid content in ethyl acetate fraction, and the best antibacterial activity in ethyl acetate fraction. Correlation between total flavonoid content from extract and fraction (Abelmoschus manihot L.) with antibacterial activity against Staphylococcus aureus bacteria on ethyl acetate fraction, $n$-hexane fraction, and ethanol extract at a concentration of $1000 \mu \mathrm{g} / \mathrm{mL}$ had good values with kneeling significance values according to 0.012 ( $p<0.05), 0.034$ ( $p<0.05)$, and 0.023 ( $p<0.05)$ with total flavonoid content affecting how much antibacterial activity is $40 \%$ for ethyl acetate fraction, 35\% fraction $n$-heksane and $33 \%$ ethanol extract.
\end{abstract}

Keywords $\quad$ : Antibacterial, Total Flavonoids, Staphylococcus aureus, Abelmoschus manihot L.

\section{ABSTRAK}

Salah satu komponen kimia yang sering dilaporkan memiliki aktivitas farmakologi terhadap pengobatan atau pencegahan penyakit adalah flavonoid yang dapat ditemukan pada daun gedi hijau. Staphylococcus aureus merupakan kuman penyebab utama infeksi pada manusia yang dapat menyebabkan berbagai infeksi berat. Penelitian ini bertujuan menentukan kandungan flavonoid total, aktivitas antibakteri dan korelasi antara flavonoid total dengan aktivitas antibakteri dari ekstrak dan fraksi (Abelmoschus manihot L.). Metode penelitian ini dilakukan dengan mendapatkan hasil kandungan flavonoid total, uji aktivitas antibakteri dengan cara dilusi menggunakan kontrol positif ciprofloxacin. Hasil penelitian didapatkan kandungan flavonoid total tertinggi pada fraksi etil asetat, dan aktivitas antibakteri paling bagus pada fraksi etil asetat. Korelasi antara kandungan flavonoid total dari ekstrak dan fraksi (Abelmoschus manihot L.) dengan aktivitas antibakteri terhadap bakteri Staphylococcus aureus pada fraksi etil asetat, fraksi n-heksane, dan ekstrak etanol pada konsentrasi $1000 \mu \mathrm{g} / \mathrm{mL}$ memiliki nilai yang baik baik dengan nilai signifikansi bertutut-turut $0,012$ ( $\mathrm{p}<0,05), 0,034(\mathrm{p}<0,05)$, dan $0,023(\mathrm{p}<0,05)$ dengan kandungan flavonoid total mempengaruhi seberapa besar aktivitas antibakteri yaitu $40 \%$ untuk fraksi etil asetat, 35\% fraksi n-heksane dan 33\% ekstrak etanol.

Kata kunci $\quad$ : Antibakteri, Flavonoid Total, Staphylococcus aureus, Abelmoschus manihot L. 
PHARMACON- PROGRAM STUDI FARMASI, FMIPA, UNIVERSITAS SAM RATULANGI,

Volume 8 Nomor 3 Agustus 2019

\section{PENDAHULUAN}

Salah satu komponen kimia yang sering dilaporkan memiliki aktivitas farmakologi terhadap pengobatan atau pencegahan penyakit adalah flavanoid. Senyawa flavanoid terdapat pada semua tubuh tumbuhan yaitu akar, batang, daun, buah, biji dan bunga. Beberapa tanaman obat yang mengandung flavanoid memiliki aktivitas antioksidan, antibakteri, antivirus, antiradang, antialergi, antikanker dan antibakteri (Ipandi, 2016).

Angka kejadian penyakit infeksi terus meningkat dalam beberapa tahun terakhir. Penyakit infeksi yang disebabkan bakteri banyak menyerang penduduk di negara berkembang, termasuk Indonesia.

Staphylococcus aureus merupakan kuman penyebab utama infeksi pada manusia yang dapat menyebabkan berbagai infeksi berat yang terjadi baik di komunitas maupun rumah sakit (Dellyna, 2014).

Staphylococcus aureus merupakan salah satu bakteri patogen penting yang berkaitan dengan virulensi toksin, invasif, dan ketahanan terhadap antibiotik. Ajizah et al. (2007) menyatakan bahwa bakteri Staphylococcus aureus dapat menyebabkan terjadinya berbagai jenis infeksi mulai dari infeksi kulit ringan, keracunan makanan sampai dengan infeksi sistemik. Infeksi yang terjadi misalnya keracunan makanan karena Staphylococcus, salah satu jenis faktor virulensi yaitu Staphylococcus enterotoxin (Ses). Gejala keracunan makanan akibat Staphylococcus adalah kram perut, muntah-muntah yang kadang-kadang di ikuti oleh diare (Brown et al, 2005).

Salah satu tumbuhan yang mengandung senyawa flavanoid dan digunakan untuk pengobatan tradisional adalah daun gedi (Abelmoschus manihot L.), sinonimnya (Hibiscus manihot L.), suku malvacae. Di
Sulawesi Utara daun gedi telah lama dikenal dan dimanfaatkan sebagai sayuran, dengan nama sayur yondok (Mandey, 2013). Mamahit dan soekamto (2010) melaporkan bahwa masyarakat juga memanfaatkan sebagai obat tradisional dengan cara merebus tanpa garam untuk mengobati penyakit ginjal, maag, kolesterol, demam dan rematik.

Gedi (Abelmoschus manihot L.) merupakan tanaman tropis famili Malvacea. Sebagian kecil penduduk Indonesia memanfaatkan bagian daun gedi sebagai bahan pangan. Sri Sudewi et al (2017) melaporkan terdapat kandungan flavonoid total dan fenolik total serta aktivitas penangkal radikal bebas dalam ekstrak daun gedi yang di ambil dari Kota Minahasa, Minahasa Utara, Minahasa Selatan, Minahasa Tenggara, Bitung, Manado, Tomohon, dan Kotamobagu. Daun gedi memiliki flavonoid total terbesar pada sampel dari Minahasa Tenggara sebesar 38,104\%.

\section{METODOLOGI PENELITIAN}

Alat

Alat-alat ukur analitis yang digunakan ialah Spektrofotometri UV-VIS (Shimadzu 00780), Komputer pengolah data (Acer Aspie ES 11), Alat-alat gelas, Vortex (Mixer Hwashin), Blender (Phillips) Rotary Evaporator (RV 10 digital V), alat maserasi (Pyrex), neraca analitik (Mettler Toledo tipe PL 303, Dragon 205), Rotary evaporator (Heidolph tipe Heizbad WB), waterbath, corong pisah (Pyrex), pipet ukur dengan berbagai ukuran (Pyrex), autoklaf, LAF (ESCO Class II BSC), incubator (Memmert), mikropipet.

\section{Bahan}

Bahan-bahan yang dipakai ialah simplisia kering daun gedi hijau (daerah Minahasa Tenggara), etanol 96\%), etanol p.a, n-heksane (Merck), etil asetat (Merck), aquadest, 
Volume 8 Nomor 3 Agustus 2019

Staphylococcus aureus ATCC 25923 yang diperoleh dari Laboratorium Mikrobiologi farmasi unsrat, Standar kuersetin, Nutrient Agar (NA), Nutrient Broth (NB), DMSO, Antibiotik Ciprofloxacin, Larutan standar McFarland, $\mathrm{NaCl}, \mathrm{AlCl} 3$ (Merck), $\mathrm{CH}_{3} \mathrm{COOH}$ (Merck)

\section{Prosedur Kerja}

\section{Pengambilan sampel}

Sampel daun Gedi Hijau (Abelmoschus manihot L.) diambil dari Minahasa Tenggara. Selanjutnya sampel daun gedi hijau (Abelmoschus manihot L.) dibuat menjadi bentuk simplisia. Kemudian simplisia dibuat menjadi ekstrak menggunakan metode maserasi.

\section{Ekstraksi}

Sebanyak 75 gram serbuk simplisia dimasukkan ke dalam maserator $375 \mathrm{~mL}$ dan kemudian ditambahkan etanol 96\%. Ekstraksi dilakukan dengan cara maserasi selama 24 jam dengan beberapa kali pengocokan. Ekstrak hasil maserasi kemudian diuapkan dengan rotary evaporator hingga terbentuk ekstrak kental.

\section{Fraksinasi}

Sebanyak 5 g ekstrak kental sampel dilarutkan dengan $25 \mathrm{~mL}$ air. Larutan selanjutnya difraksinasi dengan $50 \mathrm{~mL} n-$ heksan. Dikocok dalam labu pemisah dan didiamkan selama 10-15 menit hingga terdapat dua lapisan air (air pada lapisan bawah dan nheksan pada lapisan atas). Kedua lapisan yang terbentuk kemudian dipisahkan. Proses penambahan n-heksan pada lapisan bawah (air) yang sudah dipisahkan diulangi dua kali. Lapisan atas (n-heksan) yang terbentuk selama tiga kali fraksinasi digabungkan dan disebut dengan fraksi n-heksan. Bagian air sisa dari proses fraksinasi yang terjadi sama dengan proses fraksinasi n-heksan kemudian difraksi lebih lanjut dengan etil asetat. Proses yang terjadi sama dengan proses fraksinasi dari $\mathrm{n}$ heksan. Lapisan etil asetat yang nantinya akan terbentuk selama tiga kali fraksinasi digabungkan dan disebut sebagai fraksi etil asetat dan sisa lapisan aquadest disebut sebagai fraksi aquadest.

\section{Dilusi}

Untuk Masing-masing tabung yang telah disiapkan dimasukan 1,4 ml Nutrien Broth (NB) lalu ditambahkan $0,5 \mathrm{~mL}$ larutan uji. Kemudian tiap-tiap tabung ditambahkan $0,1 \mathrm{~mL}$ suspensi bakteri S.Aureus dan di vortex. Sebelum diinkubasi, setiap tabung dilusi diamati secara seksama dan liat absorbansi pada spektrofotometer UV-VIS pada panjang gelombang $600 \mathrm{~nm}$. Kemudian seluruh tabung diinkubasi pada suhu $37^{\circ} \mathrm{C}$ selama $18-24$ jam. Setelah inkubasi, setiap tabung dilusi kembali diamati secara seksama dan diliat kembali absorbansinya pada spektrofotometer UV-VIS dengan panjang gelombang $600 \mathrm{~nm}$. Dibandingkan hasil pengamatan kekeruhan antara sebelum dan sesudah proses inkubasi serta dibandingkan nilai absorbansi sebelum dan sesudah proses inkubasi, adanya peningkatan nilai absorbansi setelah inkubasi menunjukan adanya pertumbuhan bakteri, sedangkan nilai yang tetap dan berkurang absorbansinya setelah inkubasi menunjukan tidak adanya pertumbuhan bakteri sehingga dapat dianggap pada konsentrasi ini adalah KHM (Konsentrasi Hambat Minimum) yang dapat menghambat pertumbuhan. Selanjutnya untuk membuktikan apakah sampel memiliki kemampuan membunuh, maka dilakukan penentuan KBM (Konsentrasi Bunuh Minimal) yaitu dengan mengambil 1 ose dari masingmasing tabung kemudian diinokulasi pada media Nutrient Agar dalam cawan petri dan diinkubasi selama $18-24$ jam pada suhu $37^{\circ} \mathrm{C}$. Replikasi dilakukan sebanyak 3 kali. Setelah 
Volume 8 Nomor 3 Agustus 2019

diinkubasi diamati jika ada pertumbuhan bakteri berarti sampel bersifat bakteriostatik, dan apabila sampel tidak menunjukan adanya pertumbuhan bakteri maka dapat disebut sampel bersifat bakterisidal.

\section{Pengukuran Kadar Flavonoid Total}

Total flavonoid dari ekstrak dan fraksifraksi daun gedi hijau dihitung berdasarkan metode kolorimetri yang dilakukan oleh Chang et al. (2002). Setiap 0,2 $\mathrm{mL}$ larutan sampel ditambahkan 3,7 mL etanol 95\%, 0,1 $\mathrm{mL} \mathrm{AlCl}_{3}$ $10 \%, 0,1 \mathrm{~mL}$ kalium asetat $1 \mathrm{M}$ dan ditam bahkan aquades hingga tanda batas, lalu dicampur hingga homogen dan didiamkan selama waktu inkubasi yang paling optimal. Kemudian diukur absorbansinya pada panjang gelombang maksimum. Kadar flavonoid total dihitung ekuivalen dengan jumlah (g) kuersetin/100 g sampel. Penentuan nilai flavonoid akhir dilakukan berdasarkan formula yang dikembangkan oleh Pan et al. (2012), yaitu:

$$
\text { Flavonoid Total }=\left(\frac{\mathrm{m}}{\mathrm{g}}\right)=\frac{\mathrm{Y} \times \mathrm{NxV}}{\mathrm{W}}
$$

Keterangan :

$\mathrm{Y}=$ konsentrasi flavonoid contoh yang dihitung dengan menggunakan persamaan kurva standard ( $\mathrm{mg} \mathrm{g}^{-1}$ )

$\mathrm{N}=$ Faktor pengenceran.

$\mathrm{V}=$ volume Sampel $(\mathrm{mL})$.

$\mathrm{W}=$ berat Sampel $(\mathrm{g})$.

\section{Analisis Data}

Analisis data dengan menggunakan program Microsoft Excel dan spss. Data yang diperoleh kemudian dianalisis menggunakan metode One Sample Kolmogorov Smirnov test dengan taraf kepercayaan 95\% untuk melihat apakah data yang diperoleh tiap kelompok terdistribusi normal atau tidak. Apabila terdistribusi normal, setelah itu dilihat korelasi antara keduanya menggunakan korelasi Pearson dan regresi linear sederhana.

\section{HASIL DAN PEMBAHASAN \\ Determinasi Sampel}

Determinasi sampel dilakukan di Laboratorium Taksonomi Tumbuhan Jurusan Biologi, Fakultas Matematika dan Ilmu Pengetahuan Alam, Universitas Sam Ratulangi, Manado. Determinasi tumbuhan merupakan proses dalam menentukan nama atau jenis tumbuhan secara spesifik. Determinasi tumbuhan bertujuan untuk memastikan kebenaran identitas dari tanaman yang akan digunakan dalam penelitian sehingga pada saat pengambilan sampel tidak terjadi kesalahan. Hasil determinasi menunjukkan bahwa tanaman yang digunakan dalam penelitian ini adalah Abelmoschus manihot $\mathrm{L}$.

\section{Preparasi Sampel}

Daun gedi hijau yang telah diambil dari daerah Minahasa Tenggara, disortasi basah untuk menghilangkan tanah, kerikil, rumputrumputan, bagian tanaman lain atau bagian lain yang tidak digunakan dan bagian daun yang rusak. Kemudian dicuci untuk menghilangkan kotoran dan getah yang menempel pada daun gedi hijau dan dikeringkan diruangan terbuka dengan panas ruangan selama 5 hari. Pengeringan ini bertujuan untuk mengurangi kadar air didalam daun, dari tumbuhnya jamur sehingga mendapatkan sampel dengan senyawa kimia yang tidak mudah rusak, dan dapat disimpan dalam waktu yang lebih lama.

\section{Ekstraksi}

Ekstraksi dilakukan dengan cara maserasi selama 24 jam dengan beberapa kali pengocokan. Metode maserasi ini digunakan karena memiliki keuntungan dimana prosedur dan peralatannya sederhana dan mudah (Agoes, 
Volume 8 Nomor 3 Agustus 2019

2007), serta dapat menghindari adanya perubahan kimia terhadap senyawa-senyawa tertentu oleh karena pemanasan.

Ekstraksi merupakan langkah awal dalam memisahkan komponen bioaktif. Ekstraksi dengan pelarut sering digunakan untuk mengekstraksi senyawa bioaktif tanaman. Ekstraksi antioksidan tanaman tergantung pada kelarutan komponen antioksidan dari tanaman dalam pelarut (Spigno et al., 2010).

Maserasi dilakukan selama 24 jam dengan beberapa kali pengocokan dengan tujuan agar senyawa yang terdapat dalam sampel dapat tertarik, kemudian dilakukan penyaringan dan didapatkan filtrat dan residu, selanjutnya filtrat yang di dapat akan diuapkan dengan di masukan kedalam oven dengan suhu $40^{\circ} \mathrm{c}$ untuk menguapkan pelarut serta tidak merusak senyawa yang terkandung dalam ekstrak, hingga diperoleh ekstrak kental. Setelah proses ekstraksi didapatkan hasil rendemen dari ekstrak daun gedi hijau yaitu 6,80\% dari 250 gram berat sampel daun gedi hijau.

\section{Fraksinasi}

Fraksinasi dilakukan dengan menggunakan teknik partisi yaitu menggunakan corong pisah, teknik partisi ini adalah cara yang sederhana. Partisi adalah proses pemisahan untuk memperoleh komponen zat terlarut dari campurannya dalam padatan dengan menggunakan pelarut yang sesuai (Kwon, 2001) dimana prinsip dari partisi adalah digunakannya dua pelarut yang tidak saling bercampur untuk melarutkan zat-zat yang ada dalam ekstrak. Pada proses ini zat yang ada dalam ekstrak akan berpindah atau terdistibusi kedalam fasenya sendiri sesuai dengan kelarutannya terhadap fase tersebut dua pelarut yang tidaks aling bercampur dimasukan kedalam corong pisah beserta ekstrak dan akan dikocok setelah itu didiamkan beberapa saat setelah itu akan terbentuk 2 lapisan dimana pelarut yang memiliki kelarutan lebih besar pada lapisan bawah dan pelarut yang memiliki kelarutan lebih kecil berada di atas.

\section{Operating Time dan Penentuan Panjang Gelombang Maksimum}

\section{a. Operating Time}

Menurut hasil yang didapat dari pengukuran operating time waktu ke 1 hingga ke 20 menunjukan angka yang stabil atau tetap. Operating time merupakan waktu yang dibutuhkan oleh larutan untuk mencapai absorbansi yang konstan dimana pada rentan waktu ini adalah saat dimana larutan memiliki tingkat absorbansi yang baik dan lebih optimal dibanding dengan waktu yang memiliki absorbansi yang berubah-ubah.

\section{b. Penetuan Panjang Gelombang Maksimum}

Pada penelitian ini panjang gelombang maksimum dilakukan untuk mengetahui pada serapan berapa zat yang dibaca oleh spektrofotometer UV secara optimum, pada penelitian ini hasil scanning dilakukan pada rentang panjang gelombang 400-500 nm dengan menggunakan spektrofotometer UVVis. Sesuai dengan hasil yang didapat pada panjang gelombang $415 \mathrm{~nm}$ mendapat hasil absorbansi senilai 0,78 dengan menggunakan

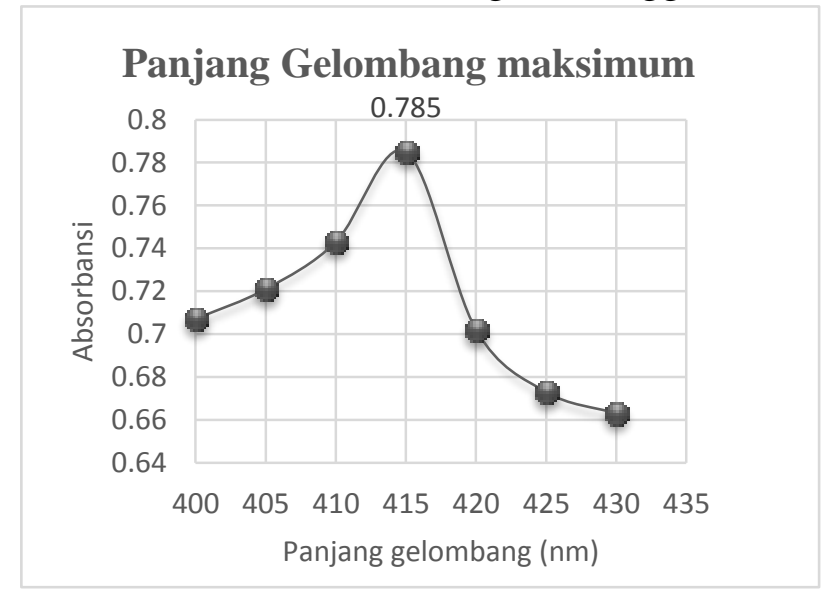

Gambar 1. Scanning panjang gelombang maksimum 
konsentrasi 40 ppm.

\section{Penentuan Kurva Baku Linearitas}

Standar kurva baku yang dilakukan dalam penelitian ini dibuat dengan beberapa seri konsentrasi 10, 20, 30, 40, dan $50 \mathrm{ppm}$ dengan hasil absorbansi yang didapat pada pengukuran panjang gelombang $415 \mathrm{~nm}$.

Berdasarkan hasil yang didapatkan bisa disimpulkan bahwa semakin tinggi konsentrasi yang digunakan maka semakin tinggi pula absorbansi yang diperoleh. Hasil kurva baku kuersetin yang diperoleh diplotkan antara konsentrasi dan absorbansinya, sehingga diperoleh persamaan regresi linear yaitu $y=0,0135 x-0,0152$ dengan nilai $R^{2}$ yang diperoleh sebesar 0,9885. Hasil persamaan kurva kalibrasi kuersetin ini mempunyai hubungan yang linear atau berbanding lurus antara konsentrasi yang dibuat dengan nilai absorbansi yang didapatkan, serta pengukuran ini sesuai dengan kriteria yang dapat di terima yaitu $\geq$ 0,98 yang dapat digunakan sebagai pembanding untuk menentukan konsentrasi senyawa flavonoid total (Basset, 1994).

\section{Penentuan Kandungan Flavonoid Total}

Penetapan kandungan flavonoid total pada Ekstrak dan Fraksi Daun Gedi Hijau ini dilakukan perhitungan dengan menggunakan persamaan Regresi Linear Kurva Baku yang telah dibuat yaitu $\mathrm{y}=0,0135 \mathrm{x}-0,0152$ yang kemudian nilai $\mathrm{x}$ akan di masukan dengan nilai rata-rata dari hasil pengukuran absorbansi ekstrak dan fraksi yang dibuat, dan didapatlah hasil kandungan flavonoid total pada ekstrak etanol sebesar 3,837 $\pm 0,033 \mathrm{mg} \mathrm{QE} / \mathrm{g}$, fraksi n-heksan 4,214 $\pm 0,01 \mathrm{mg}$ QE/g, fraksi etil asetat 5,026 $\pm 0,025 \mathrm{mg}$ QE/g dan untuk fraksi etanol sebesar 2,435 $\pm 0,007 \mathrm{mg} \mathrm{QE} / \mathrm{g}$ dan dari hasil perhitungan yang didapatkan diatas dapat diketahui bahwa nilai kandungan flavonoid total paling tinggi adalah dari fraksi etil asetat dengan nilai kandungan flavonoid yaitu 5,026 \pm $0,025 \mathrm{mg} \quad \mathrm{QE} / \mathrm{g}$, dimana hal ini juga membuktikan bahwa etil asetat mempunyai kemampuan lebih baik dalam mengikat senyawa-senyawa pada Daun Gedi hijau terutama flavonoid dibandingkan dengan pelarut

lainnya.

\section{Tabel 1. Data Kandungan Flavonoid Total}

\begin{tabular}{ccccccc}
\hline & $\mathbf{y 1}$ & $\mathbf{y 2}$ & $\overline{\boldsymbol{y}}$ & $(\mathbf{y}-\overline{\boldsymbol{y}})^{\mathbf{2}}$ & $\begin{array}{c}\text { Konsentrasi } \\
(\mathbf{x})\end{array}$ & $\begin{array}{c}\text { Kandungan } \\
\text { flavonoid } \\
\text { total } \\
\text { (ekstrak } \pm \\
\text { SD mg QE/g) }\end{array}$ \\
\hline $\begin{array}{c}\text { Ekstrak } \\
\text { Etanol }\end{array}$ & 0,349 & 0,415 & 0,382 & 0,000049 & $18,666 \mathrm{ppm}$ & $\begin{array}{c}3,837 \pm 0,033 \\
\mathrm{mg} \text { QE/g }\end{array}$ \\
\hline $\begin{array}{c}\text { Fraksi } \mathbf{N}- \\
\text { Heksane }\end{array}$ & 0,411 & 0,432 & 0,421 & 0,0001 & $32,296 \mathrm{ppm}$ & $\begin{array}{c}4,214 \pm 0,01 \\
\mathrm{mg} \mathrm{QE} / \mathrm{g}\end{array}$ \\
\hline $\begin{array}{c}\text { Fraksi Etil } \\
\text { Asetat }\end{array}$ & 0,480 & 0,531 & 0,505 & 0,000625 & $38,518 \mathrm{ppm}$ & $\begin{array}{c}5,026 \pm 0,025 \\
\mathrm{mg} \mathrm{QE} / \mathrm{g}\end{array}$ \\
\hline $\begin{array}{c}\text { Fraksi } \\
\text { Etanol }\end{array}$ & 0,244 & 0,230 & 0,237 & 0,001089 & $29,407 \mathrm{ppm}$ & $\begin{array}{c}2,435 \pm 0,007 \\
\mathrm{mg} \mathrm{QE} / \mathrm{g}\end{array}$ \\
\hline
\end{tabular}




\section{Uji Aktivitas Antibakteri}

Dalam pengujian aktivitas antibakteri dari Daun Gedi hijau digunakan bakteri Staphylococcus aureus yang adalah bakteri gram positif serta menggunakan pengujian dengan cara dilusi cair dan digunakan seri konsentrasi sebesar $1000 \mu \mathrm{g} / \mathrm{mL}, 500$ $\mu \mathrm{g} / \mathrm{mL}$, dan terakhir $250 \mu \mathrm{g} / \mathrm{mL}$. Sebagai kontrol positif dari uji ini digunakan Ciprofloxacin penggunaan antibiotik ini karena Ciprofloxacin memiliki spektrum yang luas dan bersifat bakteriostatik, sedangkan untuk kontrol negatif digunakan pelarut DMSO, Uji MIC (Minimum Inhibitory Concentration) dengan pengukuran nilai OD (optical density) yang didapatkan dengan melihat nilai absorbansi yang di lihat pada panjang gelombang $600 \mathrm{~nm}$ sebelum dan sesudah masa inkubasi selama 24 jam, untuk melihat adanya hambatan pada pertumbuhan bakteri dapat dilihat dari nilai OD yang didapat dan kemudian akan diolah menjadi $\triangle \mathrm{OD}$ yaitu nilai OD setelah inkubasi dikurangi dengan nilai OD sebelum inkubasi, untuk hasil dari $\triangle \mathrm{OD}$ positif berarti tidak adanya aktivitas antibakteri dan menunjukan jumlah sel bakteri yang meningkat sedangkan untuk nilai $\Delta \mathrm{OD}$ negatif berarti adanya aktivitas antibakteri atau turunnya jumlah sel bakteri.

\section{Korelasi Antara Kandungan Flavonoid Total dengan Aktivitas Antibakteri}

Untuk korelasi dari kandungan flavonoid total dan aktivitas antibakteri bisa didapatkan dari hasil uji nilai KBM yang di olah dengan uji Kolmogrov Smirnov, lalu dilanjutkan dengan uji Korelasi Pearson dan setelah itu uji Regresi Linear Sederhana. Pada uji yang pertama yaitu uji Kolmogrov Smirnov data nilai kbm diuji untuk melihat apakah data tersebut terdistribusi normal atau tidak hasil data yang baik / terdistribusi normal adalah nilai signifikansi > 0,05. Pada hasil uji Kolmogrov - Smirnov untuk ekstrak etanol daun gedi hijau didapat nilai 0,149, untuk fraksi n-heksane 0,200, fraksi etil assetat 0,228, dan fraksi etanol sebesar 0,145. Berdasarkan hasil diatas semua nilai berada diatas atau > 0,05 yang berarti nilai terdistribusi normal dan bisa dilanjutkan uji korelasi pearson. Untuk nilai uji korelasi pearson ekstrak etanol mendapat nilai 0,023, fraksi n-heksane 0,034, fraksi etil asetat 0,012, dan utnuk fraksi etanol mendapat nilai sebesar 0,036 dimana semua hasil signifikansi lebih kecil dari $0,05 \quad(\mathrm{p}<0,05)$ yang berarti bahwa terdapat hubungan antara konsentrasi dari ekstrak dan fraksi - fraksi daun gedi hijau terhadap jumlah koloni, untuk besaran korelasi koefisien antara konsentrasi dan koloni bakteri, fraksi etil asetat mendapat hasil -0,444, fraksi n-heksane -0,344, dan ekstrak etanol 0,300 dimana tanda negatif berarti berlawanan arah, yakni semakin besar kandungan flavonoid totalnya semkain kecil nilai KBMnya. Dengan kata lain semakin besar kandungan flavonoid totalnya, semakin besar pula aktivitas antibakterinya (Dellyna, 2014). 
Selanjutnya berdasarkan dari hasil data yang didapat dari KBM (Kadar Bunuh Minimum) pada konsentrasi 1000 $\mu \mathrm{g} / \mathrm{Ml}$ untuk etil asetat, fraksi n-heksane dan ekstrak etanol memiliki nilai yang tidak jauh berbeda dan pada hasil uji statistik untuk melihat apakah nilai berbeda secara nyata atau tidak, dan pada uji statistic didapatkan bahwa nilai tidak berbeda secara nyata sehingga dapat disimpulkan hasil KBM antara fraksi etil asetat, fraksi n-heksane, dan ekstrak etanol dikategorikan memiliki nilai KBM yang baik, menurut Galih, (2014) hal ini disebabkan karena pada kandungan fraksi etil asetat,fraksi nheksane dan ekstrak etanol dari daun gedi hijau terdapat beberapa kandungan metabolit sekunder selain flavonoid seperti tannin, yang memiliki mekanisme penghambatan pertumbuhan bakteri masing-masing. Pada tannin mampu mengkerutkan dinding sel bakteri sehingga dapat mengganggu permeabilitas sel. Terganggunya permeabilitas sel bakteri menyebabkan sel tersebut tidak dapat melakukan aktivitas hidup sehingga pertumbuhannya terhambat atau mati. Pada hasil uji Regresi Linear Sederhana pada koefisien nilai Adjusted $R$ Square nilai terbesar didaptkan oleh etil asetat yaitu 0,400 berarti sebesar $40 \%$ kandungan flavonoid total atau senyawa flavonoid memiliki aktivitas antibakteri dan sisanya $60 \%$ adalah senyawa lain yang juga memiliki aktivitas antibakteri, berikutnya ada fraksi n-heksane 0,349 atau sebesar $35 \%$ kandungan total flavonoid atau senyawa flavonoid memiliki aktivitas antibakteri dan $65 \%$ adalah senyawa lain yang juga memiliki aktivitas antibakteri, untuk ekstrak etanol dengan nilai sebesar 0,334 atau sebesar 33\% kandungan flavonoid total atau senyawa flavonoid memiliki aktivitas antibakteri dan $67 \%$ sisanya adalah senyawa lain yang juga memiliki aktivitas antibakteri. Berdasarkan hasil diatas dapat disimpulkan bahwa ekstrak dan fraksi-fraksi dari daun gedi hijau memiliki aktivitas antibakteri, serta untuk fraksi etil asetat memiliki nilai lebih tinggi dari fraksi dan ekstrak lainnya di karenakan sesuai dengan (Dellyna, 2014) kandungan flavonoid total yang lebih besar akan mempunyai efek aktivitas antibakteri yang lebih besar juga, hal ini juga membuktikan bahwa kandungan flavonoid memiliki peran penting pada aktivitas antibakteri.

\section{KESIMPULAN}

1. Kandungan flavonoid total dari ekstrak dan fraksi Abelmoschus manihot L. Diperoleh nilai untuk ekstrak etanol sebesar 3,837 $\pm 0,033 \mathrm{mg} \mathrm{QE} / \mathrm{g}$, fraksi n-heksane sebesar 4,214 $\pm 0,01 \mathrm{mg}$ $\mathrm{QE} / \mathrm{g}$, fraksi etil asetat sebesar 5,026 \pm $0,025 \mathrm{mg} \mathrm{QE} / \mathrm{g}$ dan untuk fraksi etanol sebesar 2,435 $\pm 0,007 \mathrm{mg} \mathrm{QE} / \mathrm{g}$.

2. Menurut hasil pada uji dilusi menunjukkan bahwa jumlah rata-rata koloni yang paling sedikit terdapat pada fraksi etil asetat, fraksi n-heksane dan ekstrak etanol dengan konsentrasi yang sama yaitu $1000 \mu \mathrm{g} / \mathrm{mL}$

3. Korelasi antara kandungan flavonoid total dari ekstrak dan fraksi Abelmoschus manihot L. dengan 
aktivitas antibakteri terhadap bakteri Staphylococcus aureus dianalisis menggunakan program SPSS dan menunjukkan hasil dari uji kolmogrov smirnov dimana data hasil uji $\mathrm{kbm}$ memiliki nilai signifikansi yang terdistribusi normal dengan nilai fraksi etil asetat yaitu $0,228(x>0,05)$, fraksi nheksane 0,200 $(x>0,05)$, dan ekstrak etanol $0,149 \quad(x>0,05)$ yang berarti signifikan dan dilanjutkan dengan uji Korelasi Pearson memperoleh hasil signifikan fraksi etil asetat, fraksi nheksane, dan ekstrak etanol secara berturut-turut 0,012 ( $\mathrm{p}<0,05), 0,034$ ( $\mathrm{p}$ $<0,05)$, dan $0,023 \quad(\mathrm{p}<0,05)$. Kandungan flavonoid total mempengaruhi seberapa besar aktivitas antibakteri yaitu sebesar $40 \%$ untuk etil asetat, 35\% untuk fraksi n-heksane dan $33 \%$ untuk ekstrak etanol.

\section{SARAN}

Disarankan untuk melakukan
penelitian lebih lanjut $\begin{array}{r}\text { tentang } \\ \text { bagaimana korelasi }\end{array}$ aktivitas
antioksidan dari kandungan flavonoid
total ekstrak dan fraksi daun gedi hijau
(Abelmoschus manihot L.).

\section{DAFTAR PUSTAKA}

Agoes. G. 2007. Teknologi Bahan Alam. Penerbit ITB. Bandung.

Ajizah, A., Thirhana, Mirhanuddin. 2007, Potensi Ekstrak Kayu Ulin (Eusideroxylon zwageri $\mathrm{T}$ et $\mathrm{B}$ ) dalam Menghambat Pertumbuhan Bakteri Staphylococcus aureus Secara in vitro. Bioscientiae. 4:3742.

Basset, J., R. C. Denney, G.H Jeffrey, J. Mendhom., 1994. Buku Ajar Vogel
Kimia Analisis Kuantitatif Anorganik. EGC, Jakarta.

Brown, D.F.J., Edwards, D.I., Hawkey, P.M., Morrison, D., Ridgway, G.L.,Towner, K.J., Wren, M.W.D. 2005. Guidelines for the laboratory diagnosis and susceptibility testing of methicillin-resistant Staphylococcus aureus (MRSA), Journal Antimicrob Chemother, 56, 1000-1018.

Dellyna, F. 2014. Analisis Korelasi Antara Kadar Flavonoid Dengan Aktivitas Antibakteri Ekstrak Etanol dan Fraksi-Fraksi Daun Kersen (Muntingia calabura L.) Terhadap Staphylococcus aureus. Yogyakarta : Universitas Islam Indonesia.

Ipandi, I., Triyasmono, L., Prayinto, B., 2016. Penentuan Kadar Flavonoid total dan Aktivitas Antioksidan Ekstrak Etanol daun Kajajahi (leucosyke capitella Wedd.). Program Studi Farmasi Universitas Lambung Mangurat Banjarmasin. Jurnal Farmasi. 3(1). Hal. 95-96.

Kwon, Y. 2001. Handbook of Essential Pharmacokinetics,

Pharmacodynamics and Drug Metabolism for Industrial Scientists. (secondary). New York: Kluwer Academic/Plenum Publishers. hlm. 44.

Mamahit L.P., Soekarno,N.H., 2010. Satu senyawa organic yang diisolasidari daun gedi (Albemoschus manihot L. Medik). Sulawesi utara: Chemistry Progress, Vol. 3 No. 1, P. 45.

Mandey, J. S. 2013. Daun Gedi (Abelmoschus manihot(L) Medik) Asal Sulawesi Utara Sebagai Sumber Bahan Pakan Ayam Pedaging. Disertasi. Program Pascasarjana, Universitas Brawijaya. Malang.

Pan G, G Yu, C Zhu., J Qiao. 2012. Optimization of Ultrasound- 
PHARMACONJurnal Ilmiah Farmasi - UNSRAT Vol. 8 No. 3 AGUSTUS 2019 ISSN 2302 - 2493

assisted Extraction (UAE) of Favonoids Compounds (FC) from Hawthorn Seed (HS). Ultrasonics Sonochemistry 19: 486-490.

Sudewi, S., Lolo, W., Rifai, Y., Rante, H. 2017. Analisis Finger Print Tanaman Gedi (Abelmoscus manihot L.) dengan metode Spektroskopi FTIR dan Kemometrik serta Aktivitas Penagkal Radikal Bebas. Laporan Penelitian Kemenristekdikti 2017. LPPM. UNSRAT.

Spigno, G., Tramelli, L., De Faveri, D.M. (2010). Effects of extraction time, temperature and solvent on AGRITECH, Vol. 35, No. 3, Agustus 2015287 concentration and antioxidant activity of grape marc phenolics. Journal of Food Engineering 81: 200-208 